\title{
Detection of Tetracycline Resistance Genes among Escherichia coli Isolated from Layer and Broiler Breeders in West Java, Indonesia
}

\author{
A. Indrawati ${ }^{a, *}$, K. Khoirani ${ }^{b}$, S. Setiyaningsih ${ }^{a}$, U. Affif ${ }^{a}$, Safika $^{a}$, \& S. G. Ningrum ${ }^{c}$ \\ ${ }^{a}$ Department of Animal Disease and Veterinary Public Health, Faculty of Veterinary Medicine, IPB University \\ Jalan Agatis, Kampus IPB Dramaga Bogor 16680, Indonesia \\ ${ }^{b}$ UNRAM Vocational, University of Mataram \\ Jalan Lintas Sumbawa Sondosia - Bima NTB, 84161, Indonesia \\ cFaculty of Veterinary Medicine, Universitas Wijaya Kusuma Surabaya \\ Jalan Dukuh Kupang XXV No. 54 Surabaya 60225, Indonesia \\ *Corresponding author: titin.seta@gmail.com \\ (Received 25-07-2020; Revised 10-12-2020; Accepted 23-12-2020)
}

\begin{abstract}
A major current problem in public health is the issue of antimicrobial resistance of Escherichia coli in humans and poultry. In Indonesia, multidrug-resistant $E$. coli are of specific concern since such $E$. coli may cause public health problems in humans. The prevalence of multidrug-resistant chicken $E$. coli strains and the $E$. coli resistance genes, which are $\operatorname{tet}(A)$ and $\operatorname{tet}(B)$ genes, were investigated in the present study. A total of 57 swabs were collected from layer and broiler breeder farms in West Java, Indonesia, and used in the experiment. Eighteen isolates were identified as $E$. coli by the disk diffusion method. The isolates classified as drug-resistant and intermediate were then identified using PCR for the antimicrobial resistance genes. The results showed that $\mathbf{1 8}$ isolates of E. coli from layerbreeder and broiler-breeder farms in West Java were resistant to ampicillin (100\%), nalidixic acid $(94 \%)$, tetracycline $(88 \%)$, oxytetracycline $(83 \%)$, gentamicin $(27 \%)$, and chloramphenicol $(22 \%)$. PCR identification of $E$. coli antimicrobial-resistant genes in 18 isolates showed tet(A) and tet(B) genes. This study reports antimicrobial resistance genes among $E$. coli on layer and broiler breeder farms in West Java. This present study showed that $E$. coli isolated from layers-breeder and broiler-breeder farms in West Java of Indonesia carried tet(A) and tet(B) genes, the multidrug-resistance genes.
\end{abstract}

Keywords: livestock; multidrug-resistant E. coli; layer-breeder farm; broiler-breeder farm

\section{INTRODUCTION}

Escherichia coli is a normal human inhabitant of warm-blooded intestinal flora but may also be a possible pathogenic agent. E. coli causes colibacillosis in poultry which causes significant economic losses (Amer et al., 2018). In addition, some important Enterobacteriaceae such as E. coli and Salmonella spp. can also bear antimicrobial-resistant genes, leading to multidrug resistance and the risk of spreading it to the other bacterial species, including those pathogenic to humans. Several studies revealed a high genetic similarity between E. coli in humans and poultry (Vounba et al., 2019), indicating that the chicken could serve as a reservoir of E. coli, a human pathogen. Multidrug resistance has become quite widespread in isolates of $E$. coli of livestock-origin (Alonso et al., 2017) in recent years. Since multidrug resistance is a global problem and emerging antimicrobial resistance has become a thread for public health (Zaman et al., 2017), the discovery of multidrug-resistant E. coli and the antimicrobial-resistant gene is a major public health concern.
Even though Indonesia has stopped using antimicrobial as a growth promoter, the practice of antimicrobials application in the treatment of infectious disease is widely applied (Shecho et al., 2017) in the poultry farm. Therefore, antimicrobial resistance is often caused by the use of a high dosage of antibiotics. Surprisingly, the tetracycline resistance gene was observed in some strains (Liljebjelke et al., 2017) even though tetracycline is rarely used in Indonesia. This fact indicates that there is a contamination of antimicrobial to the environment by bacteria carrying the antimicrobial-resistant gene.

A continuous monitoring system is required to assess the levels of baseline resistance and the impact of the different targeted interventions (De Kraker et al., 2017). However, there is a lack of information about multidrug-resistant E. coli in layer and broiler breeder farms in West Java, Indonesia. An investigation of multidrug-resistant E. coli is needed at poultry farms located in West Java. It is fundamental to update the latest information about multidrug-resistant $E$. coli since $E$. coli is abundant in the environment, animals, and humans.. Therefore, the present study aims to assess the trends 
of antimicrobial resistance to E. coli isolates and identify the gene resistance to $E$. coli in poultry.

\section{MATERIALS AND METHODS}

\section{Ethical Approval}

This study had no ethical approval because all methods did not harm chickens, including sample collection.

\section{Sample Collection}

A total of 57 samples (23 cloacal swabs, 14 drinking water swabs, and 20 litter swabs) were obtained from two-layer and two broiler breeder farms in West Java, Indonesia (Table 1). All of 57 samples were obtained through the use of an aseptic technique. The samples were preserved at $4^{\circ} \mathrm{C}$ and sent to the Microbiology Laboratory at the Faculty of Veterinary Medicine, IPB University, within $24 \mathrm{~h}$, for examination.

\section{Bacterial Isolation and Identification}

All specimens were tested and dispersed on Eosin Methylene Blue Agar (EMBA) (Oxoid-UK). Colonies suspected of being E. coli were isolated to Gram staining and IMViC test. A confirmation test for E. coli was performed by PCR. Genomic DNA was extracted by boiling technique (Qabajah et al., 2014). All the extracted sample isolates were examined using PCR for molecular typing of the uspA target gene using $E$. coli specific primers, having the following nucleotide sequences 5'-CCGATACGCCTGCCAATCAGT-'3 and 5'-ACGCAGACCGTAGGCCAGAT-3' (Chen \& Griffiths, 1998). Amplification of uspA gene was done in a total volume of $25 \mu \mathrm{L}$ with $50 \mathrm{ng} / \mathrm{mL}$ DNA template, 0.5 unit KAPA2G Fast Hotstart Readymix (KAPA Biosystems, Cape Town, South Africa), 0.5 pmol primers, and $\mathrm{dH}_{2} \mathrm{O}$ (DNAse, RNAse free). Temperature conditions were an initial $95^{\circ} \mathrm{C}$ denaturation step for 3 minutes followed by 35 cycles of $95^{\circ} \mathrm{C}$ for 30 seconds, $58^{\circ} \mathrm{C}$ for 30 seconds, and $72^{\circ} \mathrm{C}$ for 1 minute. In the thermal cycling system, the final cycle was followed by one cycle at $75^{\circ} \mathrm{C}$ for 5 minutes. The amplified fragments using standard PCR markers (VC 100 bp Plus BNA Ladder Vivantis) were evaluated using agarose gel electrophoresis.

\section{Antimicrobial Susceptibility Test}

Each E. coli isolate had completed antimicrobial resistance procedures according to the Clinical and Laboratory Standards Institute (CLSI) guidelines (CLSI 2018). The antibiotic susceptibility was evaluated by the disk diffusion method of Kirby Bauer using the following disks (Oxoid, UK): ampicillin (30 $\mu \mathrm{g} /$ disk), tetracycline (30 $\mu \mathrm{g} /$ disk), oxytetracycline (30 $\mu \mathrm{g} /$ disk), nalidixic acid (30 $\mu \mathrm{g} /$ disk), enrofloxacin (15 $\mu \mathrm{g} /$ disk), gentamicin $(10 \mu \mathrm{g} /$ disk $)$, and chloramphenicol $(30 \mu \mathrm{g} /$ disk). The disk diffusion method of Kirby Bauer tested the susceptibility of a target microorganism to a specific antibiotic. The disks of antibiotics were placed on an agar plate containing bacteria. After incubation, the susceptibility of bacteria against antibiotics was determined by the diameter of the ring formed on the disk. A wide ring without bacterial growth indicated that the bacteria were susceptible to the antibiotic. On the other side, a resistant bacteria was indicated by no change in the surrounding of the disk. While the intermediate one was indicated by a small inhibition zone.

\section{Multidrug Resistance Genes Detection by PCR}

All E. coli (18) and non-E. coli (2) isolates showing resistance to antimicrobial were isolated to perform DNA amplification to detect drug resistance based on the tet $(A)$ and tet $(B)$ genes using PCR machine. The non$E$. coli isolates were used in this study to determine the presence of the $\operatorname{tet}(A)$ and $\operatorname{tet}(B)$ genes in non- $E$. coli. The sequences of oligonucleotide primer and PCR conditions are listed in Table 2. PCR was performed in a total volume of $10 \mu \mathrm{L}$ with $50 \mathrm{ng} / \mathrm{mL}$ DNA template, 0.5 unit KAPA2G Fast Hotstart Readymix (KAPA Biosystems, Cape Town, South Africa), 0.5 pmol primers, and $\mathrm{dH} 2 \mathrm{O}$ (DNAse, RNAse free).

\section{RESULTS}

\section{Identification of $E$. coli Isolates Based on $u s p$ A Gene}

The biochemical tests were performed for all isolates of presumptive E. coli. Only 18 (13.5\%) identified as $E$. coli based on the presence of uspA gene by PCR (Figure 1). The information of positive samples for E. coli is shown in Table 3. In layer farm, $17.5 \%$ of E. coli were isolated only from cloacal swabs (14\%) and litter swabs $(3.5 \%)$. On the other side, the remain of E. coli $(14 \%)$ was obtained from cloacal swabs $(7 \%)$, litter swabs $(2 \%)$, and drinking water swabs (3.5\%).

\section{Multidrug Resistance}

Table 4 shows the antibiotic resistance profiles of the E. coli isolates against six antimicrobials,

Table 1. Sample collection

\begin{tabular}{lcccc}
\hline \multicolumn{1}{c}{ Farm } & N & Cloacal swabs & \multicolumn{2}{c}{ Litter swabs } \\
\hline Layer (1) & 15 & 5 & 5 & 5 \\
Layer (2) & 14 & 5 & 5 & 5 \\
Broiler (1) & 14 & 5 & 5 & 5 \\
Broiler (2) & 14 & 5 & 4 \\
Total n & 57 & 20 & 20 & 17 \\
\hline
\end{tabular}


Table 2. Oligonucleotide primer sequences and PCR conditions

\begin{tabular}{ccccc}
\hline Primer name & Sequences & Program* & Size of PCR product (bp) & References \\
\hline tet(A)-F & 5'GGTTCACTCGAACGACGTCA-3' & 1 & 577 & (Randall et al., 2004) \\
tet(A)-R & 5'-CTGTCCGACAAGTTGCATGA-3' & 1 & 577 & (Randall et al., 2004) \\
tet(B)-F & 5'-CCTCAGCTTCTCAACGCGTG-3' & 1 & 634 & (Randall et al., 2004) \\
tet(B)-R & 5'-GCACCTTGCTCATGACTCTTT-3' & 1 & 634 & (Randall et al., 2004) \\
uspA-F & 5'-CCGATACGCCTGCCAATCAGT-'3 & 2 & 884 & (Chen \& Griffiths, 1998) \\
uspA-R & 5'-ACGCAGACCGTAGGCCAGAT-3' & 2 & 884 & (Chen \& Griffiths, 1998) \\
\hline
\end{tabular}

Note: PCR program $1=x 1\left(3 \mathrm{~min}\right.$ at $\left.95^{\circ} \mathrm{C}\right), x 30\left(60 \mathrm{~s}\right.$ at $95^{\circ} \mathrm{C}, 30 \mathrm{~s}$ at $55^{\circ} \mathrm{C}, 30 \mathrm{~s}$ at $\left.73^{\circ} \mathrm{C}\right), x 1\left(5 \mathrm{~min}\right.$ at $\left.75^{\circ} \mathrm{C}\right) ; \mathrm{PCR}$ program $2=x 1\left(3 \mathrm{~min}\right.$ at $\left.95^{\circ} \mathrm{C}\right), \mathrm{x} 35(30 \mathrm{~s}$ at $95^{\circ} \mathrm{C}, 30 \mathrm{~s} 58^{\circ} \mathrm{C}, 1 \mathrm{~min}$ at $\left.72^{\circ} \mathrm{C}\right), \mathrm{x} 1\left(5 \mathrm{~min}\right.$ at $\left.75^{\circ} \mathrm{C}\right)$

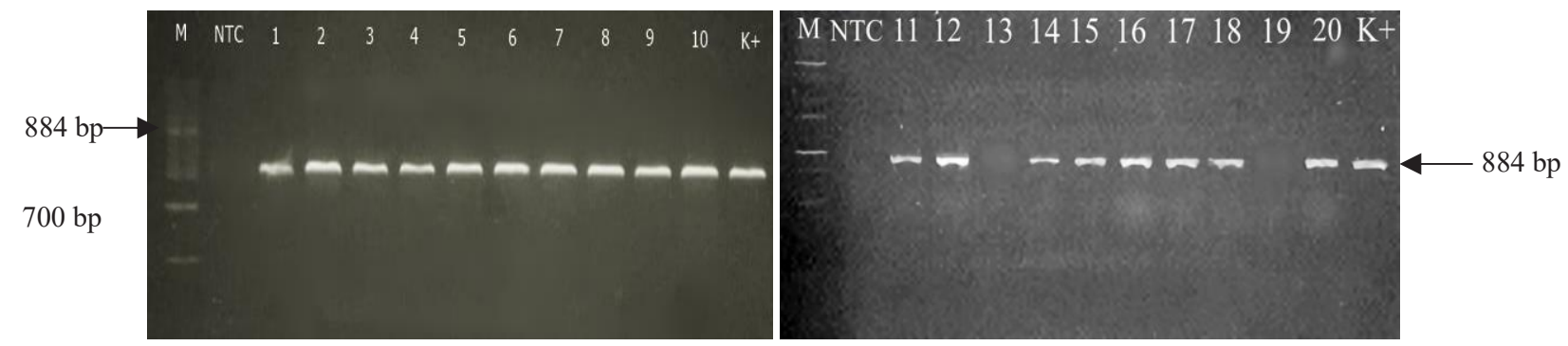

Figures 1. Amplification of the uspA gene ( $884 \mathrm{bp}$ ) encoding Escherichia coli universal stress protein A gene. A total of 18 isolates showed positive results on E. coli. $\mathrm{M}=100 \mathrm{bp}$ (marker); $\mathrm{NTC}=$ non-template control; $\mathrm{K}+=$ E. coli.

Table 3. Escherichia coli identification based on uspA gene

\begin{tabular}{lccccc}
\hline \multirow{2}{*}{ Farm } & \multicolumn{6}{c}{ No. sample positive of Escherichia coli } & \multirow{2}{*}{ Prevalence } \\
\cline { 2 - 5 } & $\mathrm{N}$ & Cloacal swabs & Litter swabs & Drinking water swabs & 0 \\
Layer (1) & 7 & 5 & 2 & 0 & $38.9 \%$ \\
Layer (2) & 3 & 3 & 0 & 0 & $16.7 \%$ \\
Broiler (1) & 3 & 1 & 2 & 2 & $16.7 \%$ \\
Broiler (2) & 5 & 3 & 0 & $2(11.1 \%)$ & $27.8 \%$ \\
Total & 18 & $12(66.7 \%)$ & $4(22.2 \%)$ & $100 \%$ \\
\hline
\end{tabular}

respectively. The results indicated that E. coli was resistant to over three of the seven antimicrobials, which were ampicillin $(100 \%)$, nalidixic acid $(94 \%)$, tetracycline $(88 \%)$, oxytetracycline $(83 \%)$, gentamicin $(27 \%)$, and chloramphenicol $(22 \%)$, in declining order.

\section{Detection of Drug Resistance Genes}

The distributions of drug-resistance genes are listed in Table 4. Figure 2 and Figure 3 show the detections of tet $(A)$ and tet $(B)$ genes based on PCR, respectively. Among the genes detected for drug resistance, the tet $(A)$ gene detection rate was the most prevalent, $94 \%(17 / 18)$, followed by the tet $(B)$ gene detection rate of $56 \%(10 / 18)$ for $E$. coli. In addition, two strains of non- $E$. coli showed a positive reaction for tet $(B)$ gene (Figure 3).

\section{DISCUSSION}

Despite the fact that E. coli can be found as a commensal bacterium in various animals, including humans in the intestinal microflora (Zhang et al., 2017), not all the strains are harmless. E. coli is known as the most common Gram-negative bacteria that can cause fatal diseases for humans and birds and also has antimicrobial resistance (Pumipuntu \& Pumipuntu, 2019). The presence of multidrug-resistant E. coli in the environment-swab samples, therefore, signals a warning for human health. A total of 18 isolates (31.5\%) from the cloacal swabs, litter, and drinking water samples were positive for the presence of the flanking regions usp A gene (Figure-1). The usp A gene has been used as a DNA marker for the identification of E. coli by Chen \& Griffiths (1998), and it is considered by another study (Godambe et al., 2017). Another report about the prevalence of E. coli in poultry from Egypt showed that $35 \%$ of the samples were positive for E. coli (Amer et al., 2018). There is a possibility that non-pathogenic E. coli will acquire virulence genes through horizontal gene transfer and causes virulent strains to emerge (Juhas, 2015).

Genes with tetracycline resistance [tet $(A)$ and tet $(B)]$ were confirmed at the prevalence of $94 \%$ and $56 \%$, respectively, the E. coli isolates (Figure-2, Figure-3). In fact, tetracycline usage for the animal is prohibited but very common in human. Based on the investigation, it indicates that there is a distribution of tetracycline resistance genes in layer-breeder and broiler-breeder farms. 
Table 4. The antibiotic resistance profiles of the isolates against six antimicrobial agents

\begin{tabular}{|c|c|c|c|c|c|c|c|c|c|c|}
\hline \multirow[t]{2}{*}{ No. } & \multirow[t]{2}{*}{ Isolates } & \multicolumn{6}{|c|}{ Antimicrobial agents } & \multirow{2}{*}{$\begin{array}{c}\begin{array}{c}\text { Escherichia coli } \\
\text { specific gene }\end{array} \\
\text { uspA }\end{array}$} & \multicolumn{2}{|c|}{ Drug resistance genes } \\
\hline & & $\mathrm{A}$ & $\mathrm{B}$ & $\mathrm{C}$ & $\mathrm{D}$ & E & $\mathrm{F}$ & & tet(A) & tet(B) \\
\hline 1 & BLc.10 & $\mathrm{R}$ & I & I & $\mathrm{I}$ & $S$ & S & + & + & + \\
\hline 2 & BLl.13 & $\mathrm{R}$ & $\mathrm{R}$ & $\mathrm{R}$ & $\mathrm{R}$ & S & S & + & + & - \\
\hline 3 & PLc.12 & $\mathrm{R}$ & $\mathrm{R}$ & $\mathrm{R}$ & $\mathrm{R}$ & I & S & + & + & + \\
\hline 4 & PLc.16 & $\mathrm{R}$ & $\mathrm{R}$ & $\mathrm{R}$ & $\mathrm{R}$ & $\mathrm{R}$ & $\mathrm{R}$ & + & + & + \\
\hline 5 & PBa.47 & $\mathrm{R}$ & $\mathrm{R}$ & $\mathrm{R}$ & $\mathrm{R}$ & $\mathrm{R}$ & $\mathrm{R}$ & + & + & - \\
\hline 6 & BLc.4 & $\mathrm{R}$ & $\mathrm{R}$ & $\mathrm{R}$ & $\mathrm{R}$ & S & $\mathrm{I}$ & + & + & - \\
\hline 7 & BLc.3 & $\mathrm{R}$ & $\mathrm{R}$ & $\mathrm{R}$ & $\mathrm{R}$ & S & S & + & - & + \\
\hline 8 & PBc.10 & $\mathrm{R}$ & $\mathrm{R}$ & I & $\mathrm{R}$ & I & I & + & + & - \\
\hline 9 & PBc. 8 & $\mathrm{R}$ & $\mathrm{R}$ & $\mathrm{R}$ & $\mathrm{R}$ & S & S & + & + & + \\
\hline 10 & BBc.18 & $\mathrm{R}$ & $\mathrm{R}$ & $\mathrm{R}$ & $\mathrm{R}$ & S & $S$ & + & + & - \\
\hline 11 & BLc. 5 & $\mathrm{R}$ & I & $\mathrm{R}$ & $\mathrm{R}$ & I & S & + & + & - \\
\hline 12 & BLc.40 & $\mathrm{R}$ & $\mathrm{R}$ & $\mathrm{R}$ & $\mathrm{R}$ & I & I & + & + & - \\
\hline 13 & PLc.15 & $\mathrm{R}$ & $\mathrm{R}$ & $\mathrm{R}$ & $\mathrm{R}$ & S & I & + & + & + \\
\hline 14 & PB1.26 & $\mathrm{R}$ & $\mathrm{R}$ & $\mathrm{R}$ & $\mathrm{R}$ & S & S & + & + & + \\
\hline 15 & Bl.1.49 & $\mathrm{R}$ & $\mathrm{R}$ & $\mathrm{R}$ & $\mathrm{R}$ & S & $S$ & + & + & + \\
\hline 16 & BBl.23 & $\mathrm{R}$ & $\mathrm{R}$ & $\mathrm{R}$ & $\mathrm{R}$ & S & $S$ & + & + & - \\
\hline 17 & PBa.42 & $\mathrm{R}$ & $\mathrm{R}$ & $\mathrm{R}$ & $\mathrm{R}$ & S & $S$ & + & + & + \\
\hline 18 & PBc.4 & $\mathrm{R}$ & $\mathrm{R}$ & $\mathrm{R}$ & $\mathrm{R}$ & I & $\mathrm{R}$ & + & + & - \\
\hline 19 & PLc.11 & $\mathrm{R}$ & $\mathrm{R}$ & I & $\mathrm{R}$ & I & I & - & - & + \\
\hline 20 & BBc.22 & $\mathrm{R}$ & $\mathrm{R}$ & $\mathrm{R}$ & $\mathrm{R}$ & $\mathrm{S}$ & I & - & + & + \\
\hline \multicolumn{2}{|c|}{ Total of E. coli } & $100 \%$ & $89 \%$ & $89 \%$ & $94 \%$ & $11 \%$ & $17 \%$ & $31.5 \%$ & $94 \%$ & $56 \%$ \\
\hline
\end{tabular}

Note: $\mathrm{A}=$ ampicillin; $\mathrm{B}=$ oxytetracycline; $\mathrm{C}=$ tetracycline; $\mathrm{D}=$ nalidixic acid; $\mathrm{E}=$ chloramphenicol; $\mathrm{F}=$ gentamicin; $\mathrm{R}=$ resistant; $\mathrm{I}=$ intermediate; $\mathrm{S}=$ susceptible.

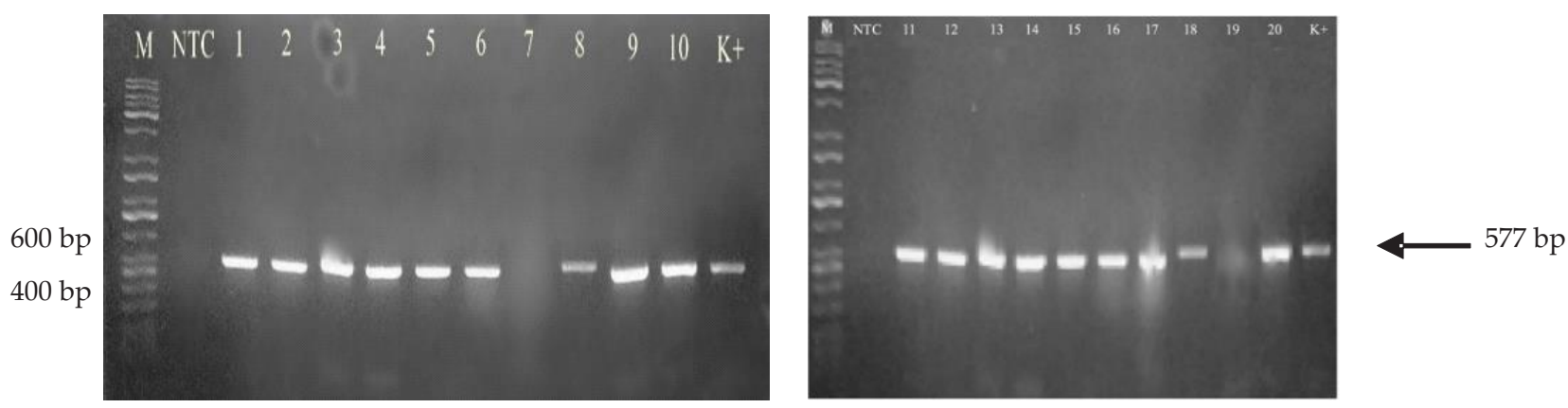

Figure 2. Amplification of the tet $(A)$ gene ( $577 \mathrm{bp})$ encoding tetracycline resistance in Escherichia coli. A total of 17 isolates of E. coli (1-18) and 1 of non- $E$. coli isolate (19-20) showed positive results on tet $(A)$. $\mathrm{M}=100 \mathrm{bp}$ (marker); NTC= nontemplate control; $\mathrm{K}+=$ positive control of $\operatorname{tet}(A)$ gene.
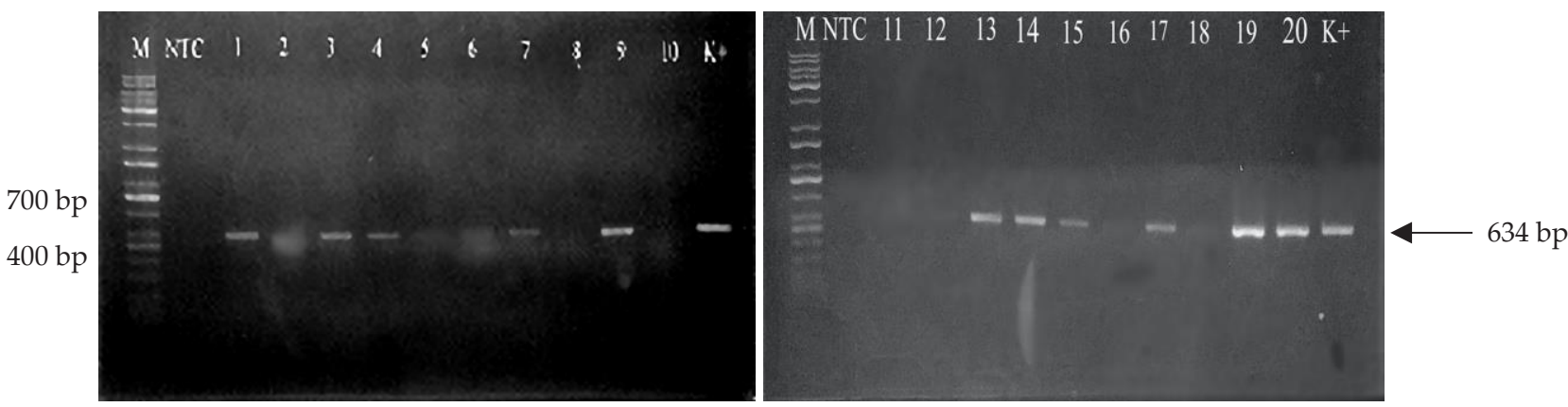

Figure 2. Amplification of the tet $(B)$ gene $(634 \mathrm{bp})$ encoding tetracycline resistance in Escherichia coli. A total of 10 isolates of E. coli (1-18) and 2 of non- $E$. coli isolates (19-20) showed positive results on tet $(B) . M=100 \mathrm{bp}$ (marker); NTC= nontemplate control; $\mathrm{K}+=$ positive control of tet $(B)$ gene. 
About $56 \%$ of the isolated strains harbored one or more tet resistance genes, and that these strains were most frequently isolated from animals living in close contact with humans (Gargano et al., 2021). In this analysis, the percentage of tetracycline resistance among E. coli $[$ tet $(A)$ and tet $(B)]$ is lower than E. coli resistant to tetracycline in Saudi Arabia (95\%) (Abo-Amer et al., 2018). The most frequently used tetracycline-resistant gene in this study was tet $(A)$ gene $(94 \%)$. In addition, tet $(A)$ gene is the most widespread determinant of Gram-positive and Gram-negative bacteria (Hedayatianfard et al., 2014) and has a wide variety of host compounds, and is often borne by specific environmental genera (Zhang et al., 2009). Besides, the present study shows that tet $(A)$ and tet $(B)$ genes are present in non- $E$. coli isolates. Recent studies have shown that tet-genes are often found on the plasmids and can be transferred horizontally between bacterial strains (Osińska et al., 2016). Meanwhile, tet $(A)$ gene has been commonly observed in various environments (Ling et al., 2013).

The high levels of resistance determined by genotyping methods and reported in the current study confirm the need for close monitoring of the use of tetracycline in poultry in West Java. This investigation might help to develop an alternative method to minimize the development and proliferation of resistant bacteria in the future, such as bacteriophage. Moreover, the high percentages of plasmid-mediated tetracycline resistance in animals may be a possible horizontal transfer of the resistance genes between strains (Veldman et al., 2011). Therefore, it is a great thread for human health.

\section{CONCLUSION}

The identification of multidrug-resistant of E. coli in layer and broiler breeder farms in West Java is still rarely done. The present study showed that E. coli isolated from layers and broiler breeder farms in West Java of Indonesia carried tet $(A)$ and $\operatorname{tet}(B)$ genes, the multidrug resistance genes.

\section{CONFLICT OF INTEREST}

We certify that there is no conflict of interest with any financial, personal, or other relationships with the other people or organization related to the material discussed in the manuscript.

\section{ACKNOWLEDGEMENT}

This work was supported by a grant from INSINAS RESEARCH PRATAMA INDIVIDU (12/INS-1/PPK/ $\mathrm{E} \$ / 2018)$. We wish to thank the College of Veterinary Medicine at IPB University, Prof. Dr. Fachriyan $\mathrm{H}$ Pasaribu, for supporting this work and the poultry companies, PT Charoen Pokphand, for their participation in the current study.

\section{REFERENCES}

Abo-Amer, A. E., M. Y. Shobrak, \& A. D. Altalhi. 2018. Isolation and antimicrobial resistance of Escherichia coli isolated from farm chickens in Taif, Saudi Arabia. J Glob. Antimicrob. Resist. 15:65-68. https://doi.org/10.1016/j.jgar.2018.05.020

Alonso, C. A., M. Zarazaga, R. Ben Sallem, A. Jouini, K. Ben Slama, \& C. Torres. 2017. Antibiotic resistance in Escherichia coli in husbandry animals: The African perspective. Lett. Appl. Microbiol. 64:318-334. https://doi. org/10.1111/lam.12724

Amer, M. M., H. M. Mekky, A. M. Amer, \& H. S. Fedawy. 2018. Antimicrobial resistance genes in pathogenic Escherichia coli isolated from diseased broiler chickens in Egypt and their relationship with the phenotypic resistance characteristics. Vet. World. 11:1082. https://doi.org/10.14202/ vetworld.2018.1082-1088

Chen, J. \& M. W. Griffiths. 1998. PCR differentiation of Escherichia coli from other Gram-negative bacteria using primers derived from the nucleotide sequences flanking the gene encoding the universal stress protein. Lett. Appl. Microbiol. 27:369-371. https://doi. org/10.1046/j.1472-765X.1998.00445.x

CLSI (Clinical and Laboratory Standards Institute). 2018. Perfomance Standards for Antimicrobial Susceptibility Testing. $28^{\text {th }}$ ed. CLSI Suplement M100. Clinical and Laboratory Standars Institute, Wayne,United States.

De Kraker, M. E. A., M. Abbas, B. Huttner, \& S. Harbarth. 2017. Good epidemiological practice: A narrative review of appropriate scientific methods to evaluate the impact of antimicrobial stewardship interventions. Clin. Microbiol. Infect. 23:819-825. https://doi.org/10.1016/j.cmi.2017.05.019

Godambe, L. P., J. Bandekar, \& R. Shashidhar. 2017. Species specific PCR based detection of Escherichia coli from Indian foods. 3 Biotech. 7:1-5. https://doi.org/10.1007/ s13205-017-0784-8

Hedayatianfard, K., M. Akhlaghi, \& H. Sharifiyazdi. 2014. Detection of tetracycline resistance genes in bacteria isolated from fish farms using polymerase chain reaction. Vet. Res. Forum. 5:269.

Jones, C. H., M. Tuckman, E. Murphy, \& P. A. Bradford. 2006. Identification and sequence of a tet $(\mathrm{M})$ tetracycline resistance determinant homologue in clinical isolates of Escherichia coli. J. Bacteriol. 188:7151-7164. https://doi. org/10.1128/JB.00705-06

Juhas, M. 2015. Horizontal gene transfer in human pathogens. Crit. Rev. Microbiol. 41:101-108. https://doi.org/10.3109/10 40841X.2013.804031

Liljebjelke, K. A., C. L. Hofacre, D. G. White, S. Ayers, M. D. Lee, \& J. J. Maurer. 2017. Diversity of antimicrobial resistance phenotypes in Salmonella isolated from commercial poultry farms. Front. Vet. Sci. 4:96. https://doi.org/10.3389/ fvets.2017.00096

Ling, Z., Y, Yang, Y. Huang, S. Zou, \& T. Luan. 2013. A preliminary investigation on the occurrence and distribution of antibiotic resistance genes in the Beijiang River, South China. J. Environ. Sci. 25:1656-1661. https://doi. org/10.1016/S1001-0742(12)60223-X

Osińska, A., M. Harnisz, \& E. Korzeniewska. 2016. Prevalence of plasmid-mediated multidrug resistance determinants in fluoroquinolone-resistant bacteria isolated from sewage and surface water. Environ. Sci. Pollut. Res. 23:1081810831. https://doi.org/10.1007/s11356-016-6221-4

Pumipuntu, N. \& S. Pumipuntu. 2019. Detection of antimicrobial resistance genes of carbapenem-resistant Enterobacteriaceae in Escherichia coli isolated from the water supply of smallholder dairy farms in Saraburi and Maha Sarakham, Thailand. Int. J. One Health. 6:1-5. https://doi. org/10.14202/IJOH.2020.1-5

Qabajah, M., E. Awwad, \& Y. Ashhab. 2014. Molecular characterisation of Escherichia coli from dead broiler chickens with signs of colibacillosis and ready-to-market chicken 
meat in the West-Bank. Br. Poult. Sci. 55:442-451. https:// doi.org/10.1080/00071668.2014.935998

Randall, L. P., S. W. Cooles, M. K. Osborn, L. V. J. Piddock, \& M. J. Woodward. 2004. Antibiotic resistance genes, integrons and multiple antibiotic resistance in thirty-five serotypes of Salmonella enterica isolated from humans and animals in the UK. Antimicrob. Chemother. 53:208-216. https://doi.org/10.1093/jac/dkh070

Shecho, M., N. Thomas, J. Kemal, \& Y. Muktar. 2017. Cloacael carriage and multidrug resistance Escherichia coli O157: H7 from poultry farms, eastern Ethiopia. J. Vet. Med. 2017:8264583. https://doi.org/10.1155/2017/8264583

Veldman, K., L. M. Cavaco, D. Mevius, A. Battisti, A. Franco, N. Botteldoorn, M. Bruneau, A. Perrin-Guyomard, T. Cerny, C. De Frutos Escobar, \& B. Guerra. 2011. International collaborative study on the occurrence of plasmid-mediated quinolone resistance in Salmonella enterica and Escherichia coli isolated from animals, humans, food and the environment in 13 European countries. J. Antimicrob. Chemother. 66:1278-1286. https://doi.org/10.1093/jac/dkr084
Vounba, P., J. Arsenault, R. Bada-Alambedji, \& J. M. Fairbrother. 2019. Prevalence of antimicrobial resistance and potential pathogenicity, and possible spread of third generation cephalosporin resistance, in Escherichia coli isolated from healthy chicken farms in the region of Dakar, Senegal. PloS One. 14:e0214304. https://doi.org/10.1371/ journal.pone. 0214304

Zaman, S. B., M. A. Hussain, R. Nye, V. Mehta, K. T. Mamun, \& N. Hossain. 2017. A review on antibiotic resistance: Alarm bells are ringing. Cureus. 9:e1403. https://doi.org/10.7759/ cureus.1403

Zhang, X. X., T. Zhang, \& H. H. Fang. 2009. Antibiotic resistance genes in water environment. Appl. Microbiol. Biotech. 82:397-414. https://doi.org/10.1007/s00253-008-1829-z

Zhang, H., M. U. Rehman, K. Li, H. Luo, Y. Lan, F. Nabi, M. K. Iqbal. 2017. Antimicrobial resistance of Escherichia coli isolated from Tibetan piglets suffering from white score diarrhea. Pak. Vet. J. 37:43-6. 